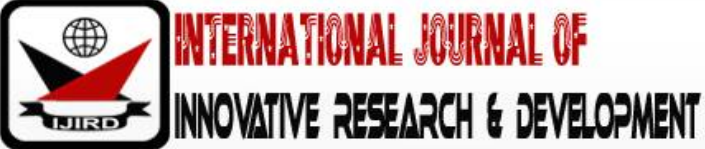

ISSN 2278 - 0211 (Online)

\section{Intra-Urban Solid Waste Disposal Practice in Selected Hospitals in Ota, Nigeria}

\author{
Dr. Akinpelu Olusegun Peter \\ Lecturer, Department of Urban and Regional Planning, College of Environmental Sciences, \\ Bells University of Technology, Nigeria \\ Owolabi Muhydeen Adedeji \\ Student, Department of Urban and Regional Planning, College of Environmental Sciences, \\ Bells University of Technology, Nigeria
}

\begin{abstract}
:
The study examined waste disposal options employed by the different hospital authorities in Ota, Ogun State, Nigeria. This is with a view to ascertaining whether the methods are environment-friendly. Data for the research were obtained through questionnaire administration and interview. There are thirty eight (38) hospitals distributed within the five (5) wards in Ota Township. For the purpose of this study, 25\% of the hospitals were sampled. Using stratified sampling technique, two hospitals were selected from each ward. This translated to 10 hospitals. Questionnaires were administered to all cleaners in each of the hospitals, while interview was conducted on head of the hospitals and waste management team where available. Data collected were analyzed using descriptive and inferential statistics. The study shows that virtually all the surveyed hospitals adopted the same methods for disposing their medical waste components.It could be concluded that methods employed in the disposal of pathological, pharmaceutical, sharps, radioactive, infectious and general waste were inadequate. The study recommends the use of modern approach and technology in the disposal of medical waste in order to forestall inherent hazards.
\end{abstract}

Keywords: Disposal practice, healthcare, intra-urban, solid waste and Ota

\section{Introduction}

Disposal is the final stage in solid waste management activities (Hosetti, 2009). Solid waste disposal takes different form depending on the source and composition of waste. It may end up in landfill, incinerated, composite or other mode of disposal. In most of the third world countries, Nigeria inclusive, solid waste is disposed around cities and towns along the roads (Imam, Mohammed, Wilson and Cheese man, 2008). The practice has given rise to several problems such as air and water pollution, blockage of drains and sewers and health hazards to the general public. The issue is more critical when it is related to waste emanating from healthcare facilities, due to its potential to cause severe health hazards and environmental contamination. Healthcare waste disposal has become a growing concern across the world, particularly in developing countries over the last few decades (Shinee, Gombojav, Nishimura, Hamajima, and Ito, 2008).

Solid waste components disposed in healthcare facilities is diverse. It includes sharps, pathological, pharmaceutical, radioactive and chemical materials. Others are infectious and non-infectious materials (Manga, Forton, Mofor, and Woodard,2011). The components can be classified into two major categories, namely: infectious/ hazardous and non-infectious. Only $10 \%$ to $25 \%$ of medical waste is infectious and/ or hazardous, the remaining $75 \%$ to $90 \%$ are noninfectious, but comparable with domestic solid waste (Thakur and Ramesh, 2015). Infectious waste include: culture and stock of infectious agents, pathological, human blood and products of blood and used sharp instruments. Others are laboratory waste from medical, carcasses and body parts, materials from surgery or pharmaceutical activities (Manyele, 2004). Non-infectious wastes are food remnant, nylon, paper and textile among others. Medical waste components require special method for its disposal. Often infectious/ hazardous and non-infectious wastes are co-disposed, especially in lowincome countries, including Nigeria (Coker and Sridhar, 2010). The practice poses serious risks to public health and environmental quality (Ministry of Health and Social Welfare, 2006). Therefore, disposal of infectious and/ or hazardous waste in an environment-friendly manner is imperative.

It is of importance to note that improper disposal practice of hospital waste affects the people that contactedit. Waste piles also attract a variety of disease vectors, including mosquitoes and flies (Gupta and Boojh, 2006). It causes environmental pollution, unpleasant odors, and growth of insects, rodents and worms. Besides, itleads to transmission of diseases such as typhoid, cholera, HIV, tuberculosis(TB), hepatitis B and C through injuries from sharps contaminated with human blood (Abdulla, Qdais and Rabi, 2008). Moreover, antibiotics poured down the drain kill beneficial microbes and bacteria in septic systems, and dumping of healthcare waste in uncontrolled areas can have adirect environmental effect by contaminating soils and underground water (Manyele and Lyasenga 2010).According to a survey by the World Health Organization (WHO) in 22 developing countries, about $18 \%$ to $64 \%$ of healthcare facilities use inappropriate waste 
disposal methods (WHO, 2002). Researchers such as Amooel (2003), Tudor et al.(2005), Da Silva et al. (2005) and Akter (2000) reported that any negligence in the disposal of healthcare waste may be of direct or indirect adverse effect on the human health and its environment. A cursory observation of most cities in Nigeria reveals indiscriminate dumping of waste; often include medical solid waste along the street, in the drainage and road intersection. This situation if not tackled appropriately could aggravate prevalence of diseases in most of the Nigerian urban areas. Therefore, the current study examined intra-urban solid waste disposal practice in selected hospital in Ota, Nigeria.

\section{The Study Area}

Ota is situated near the boundary of Lagos State, Nigeria. It has grown steadily to become the largest industrial town in Ogun State, largely as a result of its proximity to Lagos (see Figure 1). Ota is located on latitude $6^{\circ} 42^{\prime}$ North and longitude $6^{\circ} 13^{\prime}$ East covering a land area of 1,263 square kilometres. It has a terrain of 1,010.4 square kilometres plain land and about 252.6 square kilometres bad terrain comprising of $16 \%$ riverine and $4 \%$ hilly regions (Ogun State in Map, 2005).Oral tradition had it, that Ota was founded in about 1835 by the Aworis who originated from Ile-Ife, the cradle of Yoruba's. The Aworis first settled in Oke-Ata near Abeokuta but were forced by the Egbas to move southwards to the present Ota. Ota started off as the seat of a local council as far back as 1908 under the chairmanship of the then Olota of Ota. By 1946, the local council was upgraded to a District Council, with Ota as the headquarters.

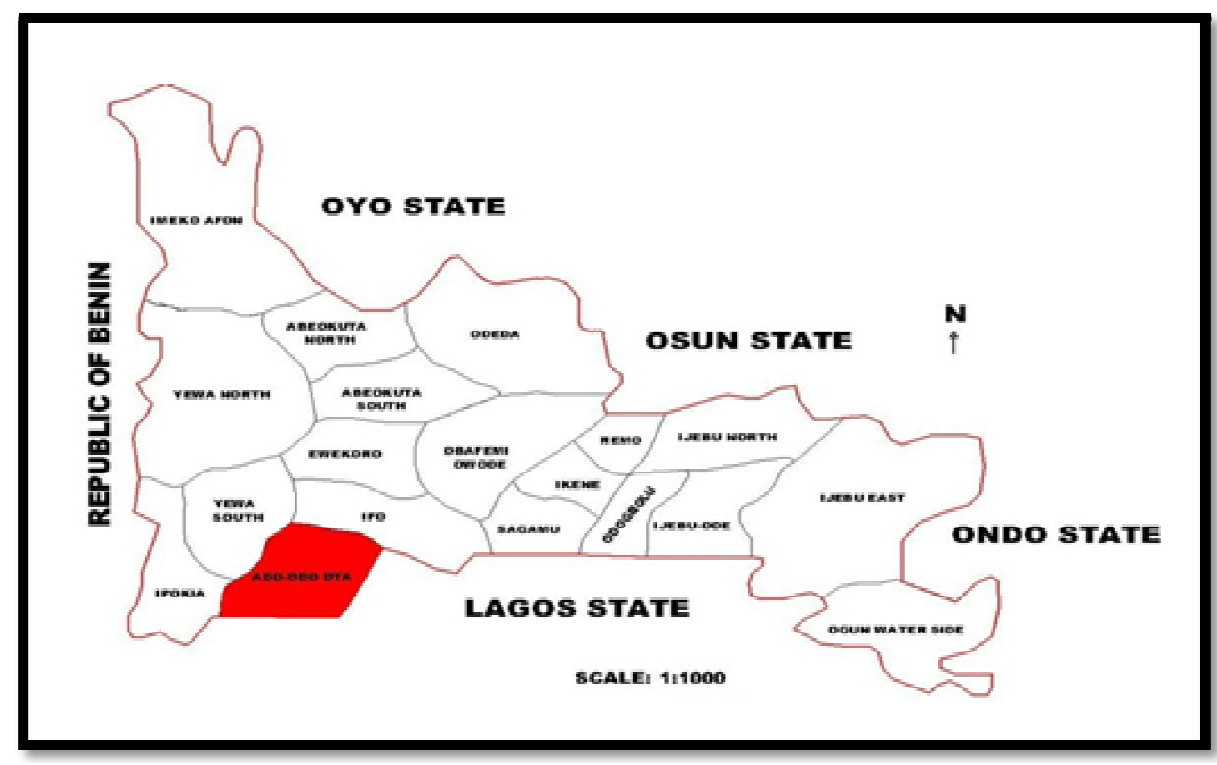

Figure 1: Ogun State Showing Ado-Odo Ota Local Government Area Source: OTA Zonal Planning Authority

It is currently head quarters of Ado-Odo/Ota Local Government (see Figure 2). Thus, administrative, sociocultural and economic life of people has changed significantly over time because of its present status.

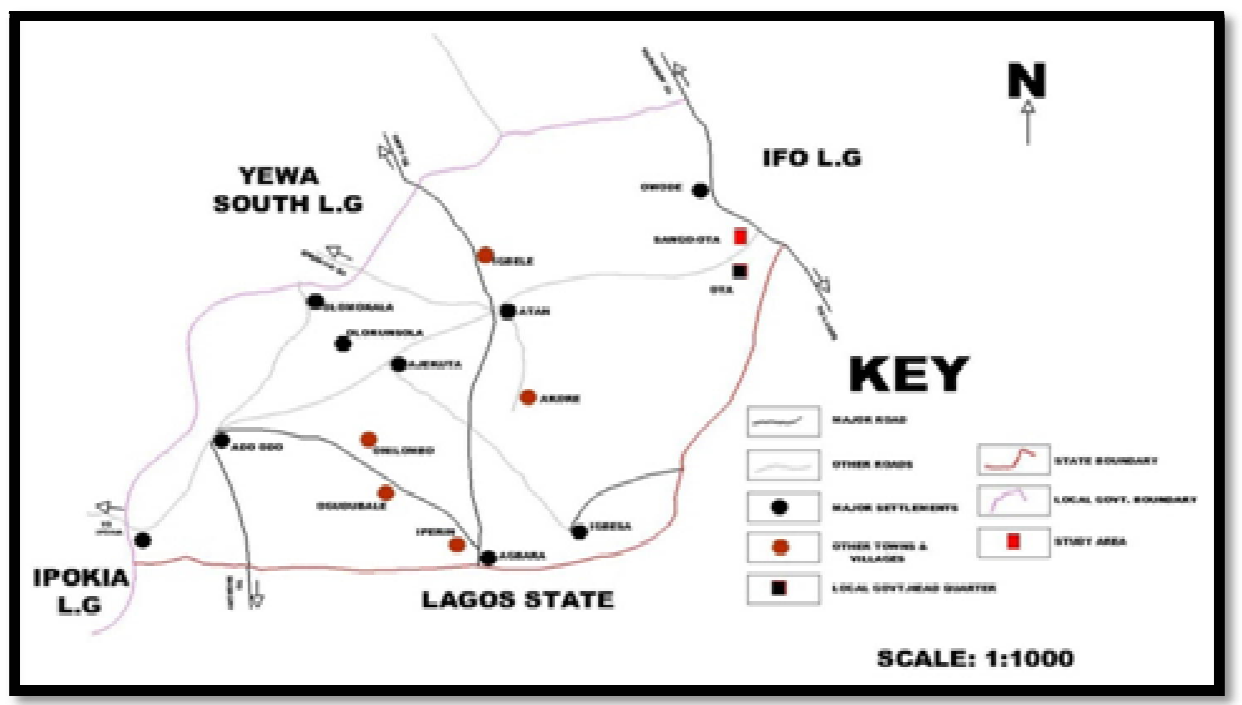

Figure 2: Ado-Odo Ota Local Government Area Source: Ota Zonal Planning Authority 


\section{Issues in Healthcare Solid Waste Disposal Practice}

Improper management of healthcare waste exposes workers and the surrounding community to infections, toxic effects and injuries. It is asserted that medical waste is capable of spreading drug-resistant microorganisms that affect human health and the quality of environment (WHO, 2015a). A survey conducted in 2015 by WHO/ UNICEF showed that $58 \%$ of sampled facilities from 24 countries adopted sustainable approach in disposing their medical waste (WHO and UNICEF, 2015b). The remaining healthcare facilities were found to employed inadequate disposal methods that could pose serious health risks. The situation is not significantly different in most healthcare facilities in Nigeria. It is of importance to note however that sharps, specifically, needles are most hazardous category of medical waste, because of the risk of needle-stick injuries which carry a high potential for infection (WHO, 2006). Healthcare or hospital solid waste components are expected to be dispose on the basis of their nature. Hazardous and/ or infectious medical waste requires treatment before final disposal in order to reduce it toxicity.

United Nations Environment Programme (2003) recommended that decontamination of infectious and sharp waste by steam (such as autoclaving) or other non-burn technology should preferably be used in the treatment of infectious waste. Steam sterilization is widely employed for instrument sterilization as well as for infectious and sharp waste. In order to ensure full decontamination of the infectious material, the process needs to be validated and regular biological, chemical and physical testing is necessary (WHO and PAHO, 2016). Steam treatment technologies need a reliable and stable electricity connection $(220 \mathrm{~V} / 380 \mathrm{~V})$. Some technologies need water of specific quality and/ or specific bags or containers. Offensive odours can be generated, if there is a large amount of organic matter in the waste andthus the location of the treatment and/ or ventilation options should be considered. Steam treatment can be combined with mechanical methods like shredding, grinding, mixing and compaction to reduce waste volume. It does not however destroy pathogens. Shredders and mixers can improve the rate of heat transfer and expose more surface area of waste for treatment. Mechanical methods should not be utilized for infectious and sharp waste before disinfection, except if the mechanical process is part of a closed system that disinfects air before it is released to the surrounding environment.

Autoclaving is the most common type of steam treatment and utilizes saturated steam under pressure to decontaminate waste. Potential infected air evacuated from the autoclave is filtered effectively (e.g. through ahigh efficiency particulate air (HEPA) filter). Autoclaves operate at temperatures of $121^{\circ} \mathrm{C}$ to $134^{\circ} \mathrm{C}$. Autoclaves which do not have an integrated shredder should ensure that the air is removed from the autoclave chamber before the waste is decontaminated, as air remaining in the waste can inhibit the decontamination efficiency of the autoclaving process.

Microwaving technology heats the water contained in the waste by microwave energy. Some microwave based devices include transformation systems like blending or shredding. Some systems are designed as batch processes and others are semi-continuous. A typical semi-continuous system uses a HEPA filter to prevent release of airborne pathogens. Waste goes through a shredder, and the waste particles are conveyed through an auger (conveyor screw) where they are further exposed to steam and heated to $100^{\circ} \mathrm{C}$ by microwave generators. Moreover, fraction heat treatment is based on friction and grinding of the waste in a moist environment. The treatment process takes place inside a chamber by means of a high-speed rotor. The temperature rises to $150^{\circ} \mathrm{C}$ and is held for the time necessary to achieve sterilization. When all the liquid contained in the waste has evaporated, it is brought to dry, superheated conditions. There sidue is a dry and unrecognizable product with reduced volume.

Incineration is a high-temperature $\left(850^{\circ} \mathrm{C}\right.$ to $\left.1100^{\circ} \mathrm{C}\right)$ dry oxidation process that reduces organic and combustible waste to inorganic, incombustible matter and results in a very significant reduction of waste volume and weight. In accordance with the Stockholm Convention, the best available technology should be used to care waste treatment. Some biological treatment systems employ enzymes to speed up the destruction of organic waste containing pathogens. Composting and vermin culture (digestion of organic wastes through the action of worms) are biological processes and have been used successfully to decompose hospital kitchen waste, as well as other organic digestible waste and placenta waste. The natural decomposition of pathological waste through burial is another example of a biological process.

General or non-hazardous and hazardous waste is not to be disposed on the premises of healthcare facilities. Nonhazardous waste should be collected regularly by the municipality or transported by the facility to a known and safely managed public disposal site. All hazardous waste must be treated to eliminate the hazardous properties before disposal, or disposed in an engineered landfill designed for hazardous waste. The disposal of pathological wastes maybe bound by socio-cultural, religious and aesthetic norms and practices. Atraditional option is the internment (burial) in cemeteries (WHO, 2014).

A situation where general or non-hazardous waste cannot be disposed at a public disposal site and there is sufficient space, an interim disposal site on the premises of the healthcare facility might be established, which is secured to prevent unauthorized access and prevents humans and animals from entering the site. The waste should be disposed and covered daily with a layer of soil. Some healthcare facilities may have neither a public disposal site nor sufficient space for disposal on the premises. As an interim (transitional) solution, the waste can be disposed in a burial area and burned. Open burning of waste results in the generation of greenhouse gases and should be avoided. The ash should be covered with a layer of soil after the burning process is finalized. The area should be secured against unauthorized access, for example with a fence. These solutions must be considered as short-term interim solutions while planning for a safer and more environmentally friendly option.

Developing countries often lack proper facilities for hazardous waste. The following options may be implemented but should be considered transitional, interim solutions. In disposing pathological waste placenta pits might be considered in low-resource settings. They need to be located at specific sites to avoid contamination of groundwater, locked and fenced for security. Natural degradation and draining of liquid into the subsoil greatly reduces the volume of waste in the pit and facilitates the inactivation of pathogens. Pathological waste may be disposed of at a landfill when no other 
treatment options are available. However, disposal should be in a pre-specified area to prevent recyclers or scavengers coming into contact with the waste.

Fly ash and bottom ash from incineration is generally considered to be hazardous, because of the possibility of heavy metal content and dioxins and furans (World Health Organisation, 2011). It should preferably be disposed in sites designed for hazardous wastes. For instance, designated cells at engineered landfills, encapsulated and placed in specialized mono-fill sites, or disposed in the ground in an ash pit. Sharp waste still pose physical risks after decontamination. There may also be risk of reuse. Decontaminated sharp waste can be disposed of in safe sharp pits on the healthcare facility premises or encapsulated by mixing waste with immobilizing material like cement before disposal. These procedures are only recommended in cases where the waste is handled manually and the landfill for general waste is not secured.

\section{Material and Methods}

The study area consists of eight (8) political wards (State Independent Electoral Commission, 2015). Five of the wards are within Ota Township. These are Wards I, II, III, Iju and Ilogbo. The remaining wards are at the out skirts, namely: Sango, Ijoko and Atan. The study focused on wards within the Township. The study utilized primary data obtained through interview and questionnaire administration. Questionnaires were administered to cleaners and waste collectors. Doctors and the head of waste contractor team were interviewed. Information obtained were type of medical waste component generated, treatment options and disposal methods. There are thirty eight (38) hospitals distributed within the five (5) wards in Ota Township (see Table 1). For the purpose of this study, 25\% of the hospitals were sampled.

\begin{tabular}{|c|c|c|}
\hline Ward & No. of Hospital & No. of Selected Hospital \\
\hline Ward 1 & 7 & 2 \\
\hline Ward 2 & 19 & 2 \\
\hline Ward 3 & 2 & 2 \\
\hline Iju Ward & 8 & 2 \\
\hline Ilogbo Ward & 2 & 2 \\
\hline Total & 38 & 10 \\
\hline
\end{tabular}

Table 1: Distribution of Hospitals in Ota Township

Using stratified sampling technique, two hospitals were selected from each ward. This translated to 10 hospitals as shown in Table 1. Questionnaires were administered to all cleaners in each of the hospitals, while interview was conducted on head of the hospitals and waste management team where available. Data collected were analyzed using descriptive and inferential statistics. Unless otherwise stated, all the tables in the study emanated from the survey of 2018.

\section{Results and Discussion}

This section focuses on the findings of the study. The findings are presented under the various sub-endings below. Discussed in this section is waste components produced, treatment and disposal methods adopted in the selected hospitals.

\subsection{Hospital Solid Waste Generation}

According to World Health Organization (1994) healthcare waste could be classified into six. These are pathological, pharmaceutical, sharps, radioactive, infectious and non-infectious (general) waste. As shown in Table 3, the hospitals generated all categories of waste components. However, radioactive waste was generated only in Osi Primary Health Centre and General hospital. Generation of radioactive materials in those hospitals might be attributed to their scope of operation. However, the fact that other hospitals did not generate radioactive waste does not rule out the potential of the remaining components produced to cause harm to human health and environment, if not properly dispose. Attention must therefore be given to its disposal in line with international best practices. This is to reduce or eliminate likelihood of health risks inherent in the waste.

\begin{tabular}{|c|c|c|c|c|c|c|c|}
\hline \multicolumn{7}{|c|}{} & \multicolumn{5}{|c|}{ Waste Component } \\
\hline s/n & Hospital & Pathological & Pharmaceutical & Sharps & Radioactive & Infectious & General \\
\hline 1 & Osi Primary Health Centre & $\checkmark$ & $\checkmark$ & $\checkmark$ & $\checkmark$ & $\checkmark$ & $\checkmark$ \\
\hline 2 & Tifeoluwa Clinic \& Maternity & $\checkmark$ & $\checkmark$ & $\checkmark$ & & $\checkmark$ & $\checkmark$ \\
\hline 3 & General Hospital & $\checkmark$ & $\checkmark$ & $\checkmark$ & $\checkmark$ & $\checkmark$ & $\checkmark$ \\
\hline 4 & Central Specialist & $\checkmark$ & $\checkmark$ & $\checkmark$ & & $\checkmark$ & $\checkmark$ \\
\hline 5 & Faramed Clinic & $\checkmark$ & $\checkmark$ & $\checkmark$ & & $\checkmark$ & $\checkmark$ \\
\hline 6 & $\begin{array}{c}\text { Twins Hospital \& Medical } \\
\text { Centre }\end{array}$ & $\checkmark$ & $\checkmark$ & $\checkmark$ & & $\checkmark$ & $\checkmark$ \\
\hline 7 & Knownfit Medical Clinic & $\checkmark$ & $\checkmark$ & $\checkmark$ & & $\checkmark$ & $\checkmark$ \\
\hline 8 & Ace Medicare Clinics & $\checkmark$ & $\checkmark$ & $\checkmark$ & & $\checkmark$ & $\checkmark$ \\
\hline 9 & Sure Mercy Hospital & $\checkmark$ & $\checkmark$ & $\checkmark$ & & $\checkmark$ & $\checkmark$ \\
\hline \multicolumn{2}{|c|}{ Jesus Saves Clinic } & $\checkmark$ & $\checkmark$ & $\checkmark$ & & $\checkmark$ & $\checkmark$ \\
\hline
\end{tabular}

Table 3: Components of Waste in the Surveyed Hospitals 


\subsection{Hospital Solid Waste Treatment}

It is recommended that decontamination of infectious and sharp waste by steam (such as autoclaving) or other non-burn technology should preferably be used in the treatment of infectious waste (UNEP, 2003). Other healthcare waste components are expected to conform to stipulated treatment methods by international bodies. For instance, socio-cultural, religious and aesthetic norms and practices may play a significant role in the disposal of pathological waste. Atraditional option is the interment (burial) in cemeteries (WHO, 2014). Information from stakeholders (such as cleaners, collectors and head, waste management team) on waste management practices in the surveyed hospitals confirmed that infectious and/ or hazardous wastes produced in the hospitals were not subjected to proper treatment before final disposal.

\subsection{Hospital Solid Waste Disposal Practice}

Findings on methods of solid waste disposal in the selected hospitals are discussed under this section. This is to establish whether the methods conformed to international best practices.

\subsubsection{Pathological waste}

Analysis on methods adopted in the disposal of pathological waste showed that most (73.5\%) of the hospital buried pathological waste generated. Though, there were a times when the waste is disposed through other readily available means such as burning, incineration or dispose into the dumpsite as shown in Figure 3. Although, the method adopted by the majority of the hospitals conformed to temporary means of disposal as recommended by World Health Organization, however, the waste materials are expected to be treated before being bury, especially infected ones was reported to be lacking. This might result into contamination of underground water, which if taking, can pose lifethreatening health hazards. In order to establish commonality of the disposal method adopted by majority of the hospital chi-square analysis was performed. The results $\left(\mathrm{X}^{2}=23.26\right.$ and $\mathrm{p}=0.671$ ) shows that there is no significant difference in the method adopted for disposal of pathological waste in all the hospitals. In

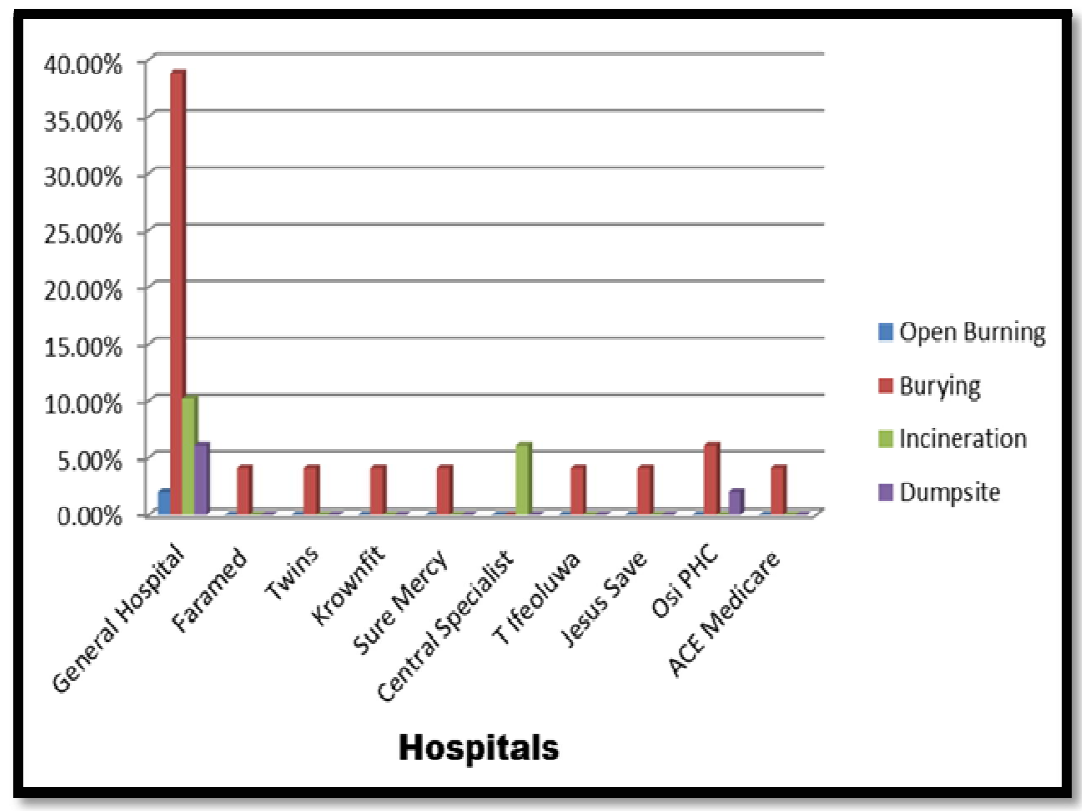

Figure 3: Pathological Waste Disposal Practice materials.

Other words, majority of the hospitals in Ota Township adopted the same approach in the disposal of pathological

\subsubsection{Pharmaceutical Waste}

As depicts in Figure 4, most (73.5\%) of hospitals in the study area adopted open burning of pharmaceutical waste. Other methods such as burying, incineration, private waste collector and municipal waste collector were occasionally employed. The approach is not environment-friendly, because of the pollutants released during the burning of the materials. Pollutants such as ash, furan and dioxin are known to be toxic, harmful and carcinogenic (World Health Organisation, 2011). This category of waste ought to be disposed through controlled incineration. In order to support the findings statistically, chi-square analysis was done. The results confirmed that there is no significant difference in the pharmaceutical waste disposal approach in the surveyed hospitals with the value of $\mathrm{X}^{2}$ of 28.70 and $\mathrm{p}$ which is significant at 0.801 . 


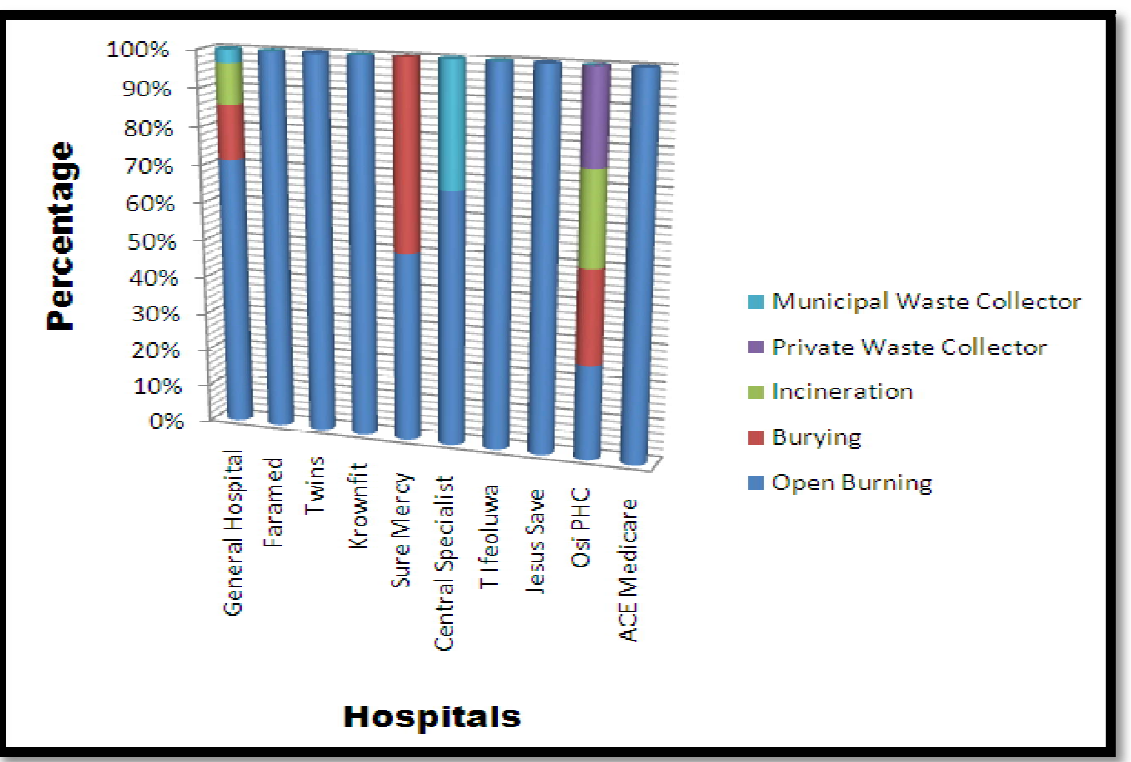

Figure 4: Pharmaceutical Waste Disposal Practice

\subsubsection{Sharp Materials}

Sharp waste is expected to be incinerated after it has been properly treated and the residue buried at a debt greater than one metre. The method adopted by $87.8 \%$ of the studied hospitals was burying. This was substantiated by the chi-square results of $\mathrm{X}^{2}=27.12$ and $\mathrm{p}=0.457$. It shows that there is no significant difference in the disposal practice adopted by hospitals in central Ota. Other methods in use were open burning, incineration and municipal collection. None of these practices are adequate in the disposal of sharp materials, because of its potential to cause hazards. This practice in no doubt will increase the tendency of contacting diseases by unsuspecting public. Consequently, budgetary allocation for combating diseases and environmental sanitation might be increased. It can therefore be concluded that the disposal practice is unsustainable. Such practice was noted in Tanzania, where most of the surveyed facilities disposed syringes and needles into shallow rubbish pits that could be retrieved for re-use (Manyele and Lyasenga, 2010).

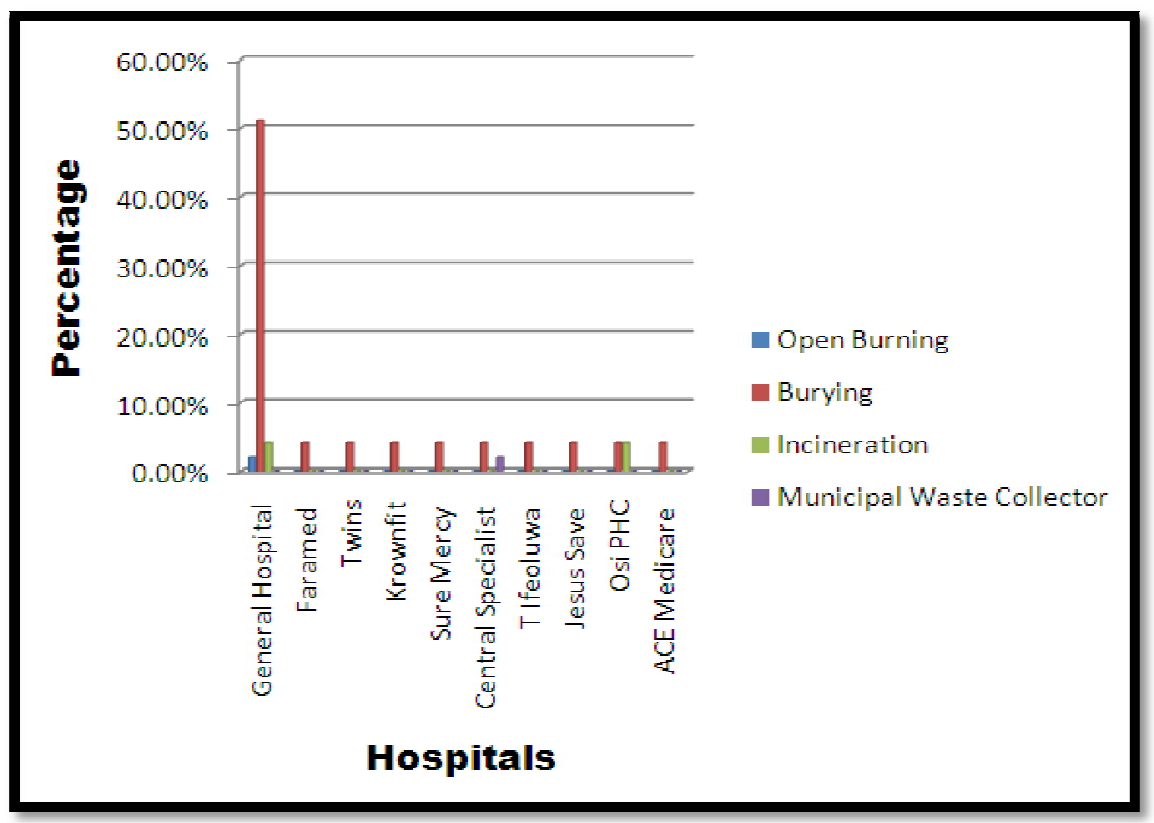

Figure 5: Sharp Waste Disposal Practice

\subsubsection{Radioactive Waste}

Radioactive waste is expected to be stored to allow decay to background level. The common practice in the surveyed hospitals was burying. Though, not all the hospitals sampled generate radioactive materials. The hospitals that produced radioactive waste were Osi Primary Health Centre and General Hospital. As shown in Figure 6, the usual method of disposing radioactive materials in these hospitals was through burying. This is not in line with the recommendation for disposing radioactive waste. Inadequate disposal of the waste might result in environmental contamination and serious health risk to human beings. The results of Chi-square indicate no significant difference in the disposal of radioactive waste among the hospitals sampled in the study area based $\left(\mathrm{X}^{2}=31.20\right.$ and $\left.\mathrm{p}=0.696\right)$. 


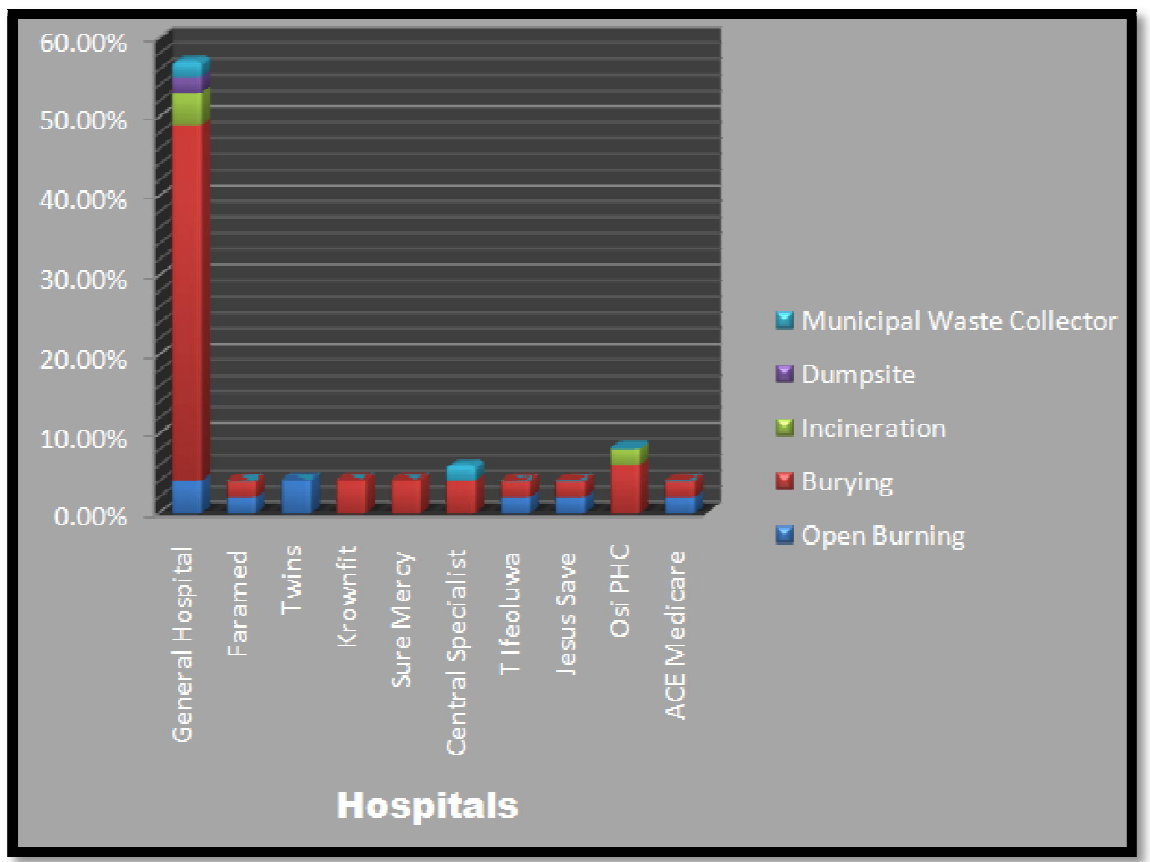

Figure 6: Radioactive Waste Disposal Practice

\subsubsection{Infectious Waste}

Findings on infectious waste disposal practice show that hospitals in Ota Township adopted open burning, burying, incineration, dumpsite and municipal waste collector. As shown in Figure 7, the method that was mostly employed by the hospitals was burying. Although, General and Central specialist hospitals made use of municipal waste collector, the hospitals often depend on burying and incineration respectively. This is corroborated by Chi-square results of $\mathrm{X}^{2}=30.52$ and $\mathrm{p}=0.724$. It shows that there is no significant difference in the approach adopted for the disposal of infectious waste by hospitals in the study area. It is of importance to note that waste was not treated before burial. This could increase the likelihood of incidence of diseases. The pathogens in waste when released contaminate the soil and water resources.

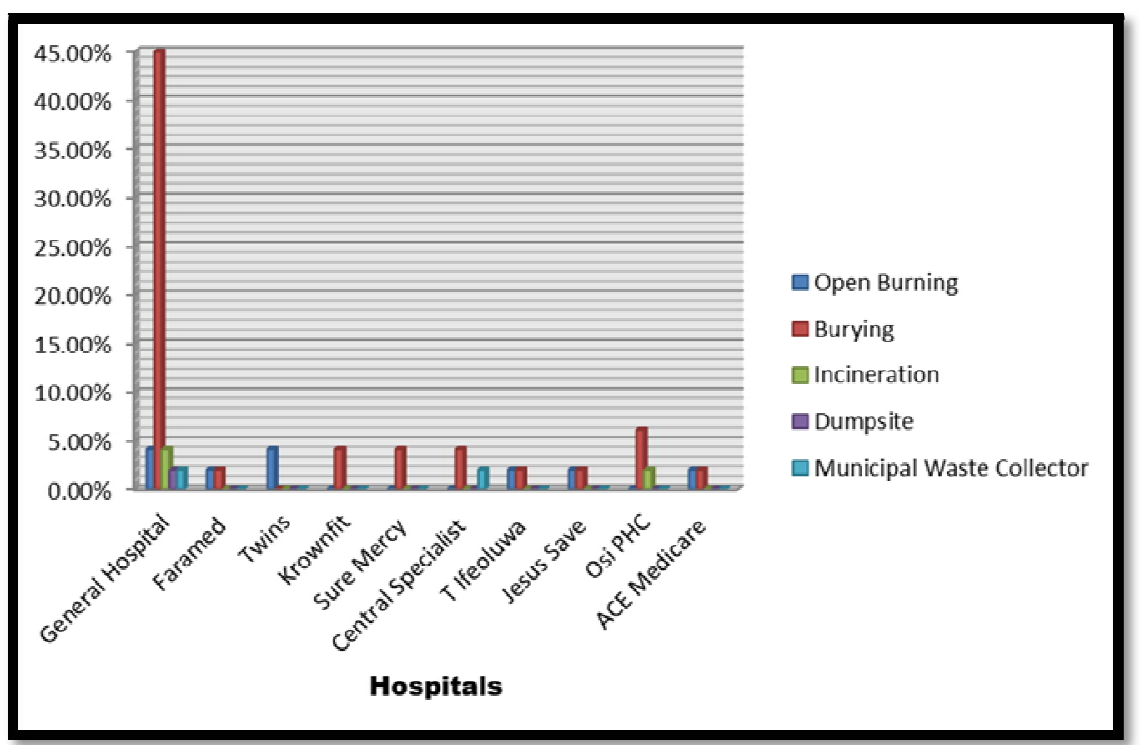

Figure 7: Infectious Waste Disposal Practice

\subsubsection{General Waste}

The results of the study show that open burning was mostly used in surveyed hospitals for disposing general waste as shown in Figure 8. Apart from open burning, other disposal methods adopted were incineration, private and municipal waste collection. The results of Chi-square analysis $\left(\mathrm{X}^{2}=28.39\right.$ and $\left.\mathrm{p}=0.392\right)$ indicates that there is no significant difference in the way and manner general waste is disposed in the selected hospitals. Open burning has been known to cause air pollution. This might be pose health risks to the people within and around the area where the burning takes place, if proper precaution in not taken. 


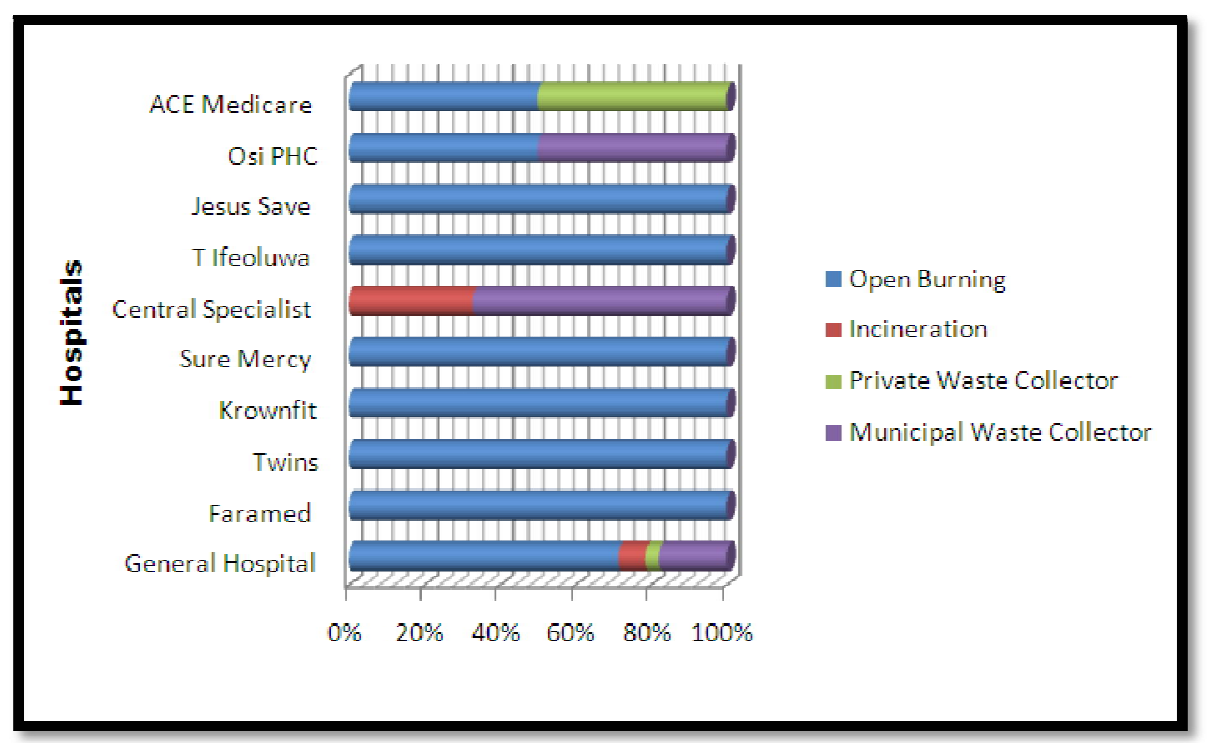

Figure 8: General Waste Disposal Practice

\section{Conclusion}

The current disposal practices of healthcare wastes components in the selected hospitals can be regarded as inadequate. Hospital is expected to safeguard the health of people, but if the waste produced is not properly disposed, then hospitals would become source of hazards to human health and the environment. In order to ensure that by-products of healthcare services are managed in a sustainable manner that would devoid of health hazards and environmental contamination, priority should be given to national and international policy and regulations on medical waste disposal, application of modern technology, adequate and regular training and capacity building of waste handlers. Information and awareness of medical waste disposal practice plan to all hospital staff and patients to keep them abreast of time and provision of adequate funding are way forward at addressing improper medical waste disposal.

\section{References}

i. Abdulla F, Abu Qdais H and Rabi A (2008). Site investigation on medical waste management practices in northern Jordan. Waste Management 28:450-458.

ii. Akter, N. (2000). Medical waste management: a review, Environmental Engineering Program, School of Environmental, Resources and development. Asian Institute of Technology, Thailand.

iii. Ali, S.M., Cotton, A.P. and Westlake, K. (1999). Down to earth: Solid waste disposal for low income countries, WEDC Loughborough University, United Kingdom

iv. Amooel, A. (2003). Determination of type and amount of solid hospital waste in Babol University Hospital, Babol University Journal; 2: 37 - 41.

v. Coker, A.O., and Sridhar, K.C. (2010). Increase in healthcare facilities and rapid environmental degradation: A technological paradox in Nigeria's Urban Centres. African Journal of Environmental Science and Technology, 4(9); 577-585.

vi. Da Silva, C., Hoppe, A., Ravanello, M. and Mello N. (2005). Medical wastes management in the south of Brazil, waste management, 25: 600 - 605.

vii. Gupta S and Boojh R (2006) Report: Biomedical waste management practicesat Balrampur Hospital, Lucknow, India. Waste Management \&Research 24: 584-591.

viii. Hosetti, B.B (2009).Prospects and perspective of solid waste management, New Age International (P) Limited, New Delhi, India

ix. Imam, A., Mohammed, B., Wilson, D.C., Cheeseman, C.R., 2008. Solid Waste Management in Abuja, Nigeria. Waste Manag. 28, 468-472. Doi:10.1016/J.Wasman.2007.01.006

x. Manga, V.E., Forton, O.T., Mofor, L.A., and Woodard, R. (2011). Health care waste management in Cameroon: A case study from the Southwestern Region. Resour Conservat Recycl. 57:108-16.

xi. Manyele, S.V. (2004). Medical waste management in Tanzania: Current situation and the way forward. African J. Environ. Assessment Management, 8 (1); 74-99.

xii. Manyele, S.V., and Lyasenga, T.J. (2010). Factors affecting medical waste management in low-level health facilities. Environmental Science and Technology, Vol. 4(5); 304-318.

xiii. Narayana T. (2009). Municipal Solid Waste Management in India: From waste management disposal to recovery ofresources. Waste Management, 29(3):1163-1166.

xiv. Ogun State in Map, (2005)

xv. Shinee, E., Gombojav, E., Nishimura, A., Hamajima, N. and Ito, K. (2008). Healthcare waste management in the capital city of Mongolia, Waste Management, vol. 28, no. 2, pp. 435-441.

xvi. Thakur, V., and Ramesh, A. (2015). Healthcare waste management research: A structured analysis and review (2005-2014), Waste Manag Res.33 (10):855-70. doi: 10.1177/ 0734242X15594248. 
xvii. Tudor, T., Noonan, C. and Jenkin L. (2005). Healthcare waste management: a case study from the National Health Service in Corwall, United Kingdom, waste management, 25: 606 - 615

xviii. UNEP (2003). Technical guidelines on the environmentally sound management of biomedical and healthcare waste. http:// archive.basel.int/ pub/ techguid/ techbiomedical.pdf (accessed 20 April 2017).

xix. World Health Organization (1994). Managing medical wastes in developing countries, WHO, Geneva

xx. World Health Organisation (2011). Healthcare waste management, cited 2015 March 10. Available from: http:/ / www.who.int/ mediacentre/ factsheets/ fs281/ en/

xxi. World Health Organisation (WHO) (2002). Waste from healthcare activities. Fact sheet no 231, April 2002. Available at http:/ / www.who.int/ mediacentre/ factsheets/ fs231/ en/ . Accessed March 15th, 2015.

xxii. WHO (2014). Safe management of wastes from health-care activities. http:// www.who.int/ water_sanitation_health/ publications/ wastemanag/ en/ (accessed 19 April 2017).

xxiii. World Health Organisation - (2015a). Healthcare waste. Fact sheet no. 253. http:// www.who.int/ mediacentre/ factsheets/ fs253/ en/ (accessed 19 April 2017).

xxiv. WHO and PAHO (2016). Decontamination and reprocessing of medical devices for healthcare facilities. http:/ / apps.who.int/ iris/ bitstream/ 10665/ 250232/ 1/ 9789241549851-eng.pdf (accessed 20 April 2017).

xxv. WHO and UNICEF (2015b). Water, sanitation and hygiene in health care facilities: Status in low- and middleincome countries and way forward. http:// www.who.int/ water_sanitation_health/ publications/ wash-health-carefacilities/ en/ (accessed 19 April 2017).

xxvi. WHO (2006). Management of waste from injection activities at the district level. Guidelines for district health managers. http:// www.who.int/ water_sanitation_health/publications/ waste-from-injections/ en/ (accessed 19 April 2017). 